\title{
Self-healing multiblock copolypeptide hydrogels via polyion complexation
}

\author{
Yintao Sun a and Timothy J. Deming ${ }^{\mathrm{a}, \mathrm{b} *}$ \\ ${ }^{a}$ Department of Bioengineering, University of California, Los Angeles, CA 90095 \\ ${ }^{\mathrm{b}}$ Department of Chemistry and Biochemistry, University of California, Los Angeles, CA \\ 90095
}

\section{Supporting Information}

Materials and instrumentation Tetrahydrofuran (THF), hexanes, and methylene chloride were dried by purging with nitrogen and passage through activated alumina columns prior to use. $\mathrm{Co}\left(\mathrm{PMe}_{3}\right)_{4}$ and amino acid N-carboxyanhydride (NCA) monomers were prepared according to literature procedures. ${ }^{1}$ All other chemicals were purchased from commercial suppliers and used without further purification unless otherwise noted. Selecto silica gel 60 (particle size $0.032-0.063 \mathrm{~mm}$ ) was used for flash column chromatography. Fourier transform infrared (FTIR) spectra were acquired on a Perkin Elmer RX1 FTIR spectrophotometer calibrated using polystyrene film, and attenuated total reflectance infrared (ATR-IR) data were collected using a Perkin Elmer Spectrum 100 FTIR spectrometer equipped with a universal ATR sample accessory. ${ }^{1} \mathrm{H}$ NMR spectra were acquired on a Bruker ARX 400 spectrometer. Tandem gel permeation chromatography/light scattering (GPC/LS) was performed using an SSI Accuflow Series III pump equipped with Wyatt DAWN EOS light scattering and Optilab REX refractive index detectors. Separations were achieved using $100 \AA$ and $1000 \AA$ PSS-PFG $7 \mu \mathrm{m}$ columns at $30{ }^{\circ} \mathrm{C}$ with $0.5 \%$ (w/w) KTFA in 1,1,1,3,3,3-hexafluoroisopropanol (HFIP) as eluent and sample concentrations of 10 
$\mathrm{mg} / \mathrm{ml}$. Pyrogen free deionized (DI) water was obtained from a Millipore Milli-Q Biocel A10 purification unit.

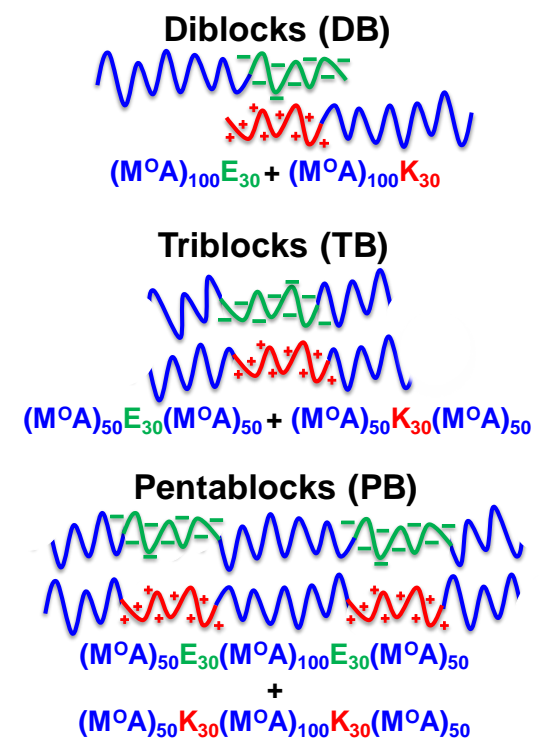

Figure S1. Schematic showing representations of diblock (DB), triblock (TB), and pentablock (PB) copolypeptides containing alternating non-ionic $\left(\mathrm{M}^{\mathrm{O}} \mathrm{A}\right)$ and ionic $(\mathrm{K}$ or $\mathrm{E})$ segments. Oppositely charged $\mathrm{K}$ and $\mathrm{E}$ domains in copolypeptides can assemble via PIC formation in aqueous media to give hydrogels.

Table S1. Characterization data for block copolypeptides.

\begin{tabular}{|c|c|c|c|c|}
\hline Architecture & Sample & $\mathbf{M}_{\mathbf{w}} / \mathbf{M}_{\mathbf{n}}{ }^{\mathbf{a}}$ & Composition $^{\mathbf{b}}$ & Yield (\%) $^{\mathbf{c}}$ \\
\hline Diblock & $\left(\mathrm{M}^{\mathrm{O}} \mathrm{A}\right)_{100} \mathrm{E}_{30}$ & 1.28 & $\left(\mathrm{M}^{\mathrm{O}} \mathrm{A}\right)_{91} \mathrm{E}_{26}$ & 95 \\
\hline Diblock & $\left(\mathrm{M}^{\mathrm{O}} \mathrm{A}\right)_{100} \mathrm{~K}_{30}$ & 1.31 & $\left(\mathrm{M}^{\mathrm{O}} \mathrm{A}\right)_{91} \mathrm{~K}_{28}$ & 93 \\
\hline Triblock & $\left(\mathrm{M}^{\mathrm{O}} \mathrm{A}\right)_{50} \mathrm{E}_{30}\left(\mathrm{M}^{\mathrm{O}} \mathrm{A}\right)_{50}$ & 1.28 & $\left(\mathrm{M}^{\mathrm{O}} \mathrm{A}\right)_{46} \mathrm{E}_{27}\left(\mathrm{M}^{\mathrm{O} A}\right)_{52}$ & 95 \\
\hline Triblock & $\left(\mathrm{M}^{\mathrm{O}} \mathrm{A}\right)_{50} \mathrm{~K}_{30}\left(\mathrm{M}^{\mathrm{O}} \mathrm{A}\right)_{50}$ & 1.26 & $\left(\mathrm{M}^{\mathrm{O}} \mathrm{A}\right)_{46} \mathrm{~K}_{29}\left(\mathrm{M}^{\mathrm{O}} \mathrm{A}\right)_{49}$ & 92 \\
\hline Pentablock & $\left(\mathrm{M}^{\mathrm{O}} \mathrm{A}\right)_{50} \mathrm{E}_{30}\left(\mathrm{M}^{\mathrm{O}} \mathrm{A}\right)_{100} \mathrm{E}_{30}\left(\mathrm{M}^{\mathrm{O}} \mathrm{A}\right)_{50}$ & 1.36 & $\left(\mathrm{M}^{\mathrm{O}} \mathrm{A}\right)_{46} \mathrm{E}_{28}\left(\mathrm{M}^{\mathrm{O}} \mathrm{A}\right)_{89} \mathrm{E}_{31}\left(\mathrm{M}^{\mathrm{O}} \mathrm{A}\right)_{48}$ & 91 \\
\hline Pentablock & $\left(\mathrm{M}^{\mathrm{O}} \mathrm{A}\right)_{50} \mathrm{~K}_{30}\left(\mathrm{M}^{\mathrm{O}} \mathrm{A}\right)_{100} \mathrm{~K}_{30}\left(\mathrm{M}^{\mathrm{O} A}\right)_{50}$ & 1.32 & $\left(\mathrm{M}^{\mathrm{O} A}\right)_{46} \mathrm{~K}_{29}\left(\mathrm{M}^{\mathrm{O}} \mathrm{A}\right)_{95} \mathrm{~K}_{31}\left(\mathrm{M}^{\mathrm{O}} \mathrm{A}\right)_{46}$ & 93 \\
\hline
\end{tabular}


${ }^{\text {a }}$ Dispersity of oxidized, protected block copolypeptides were determined by GPC/LS. ${ }^{\text {b }}$

Actual amino acid compositions of oxidized, deprotected block copolypeptides were determined by ${ }^{1} \mathrm{H}$ NMR integrations. Degree of polymerization of initial (MA) segments was determined by end-group analysis using ${ }^{1} \mathrm{H}$ NMR. ${ }^{\mathrm{c}}$ Total isolated yield of deprotected, purified block copolypeptides.
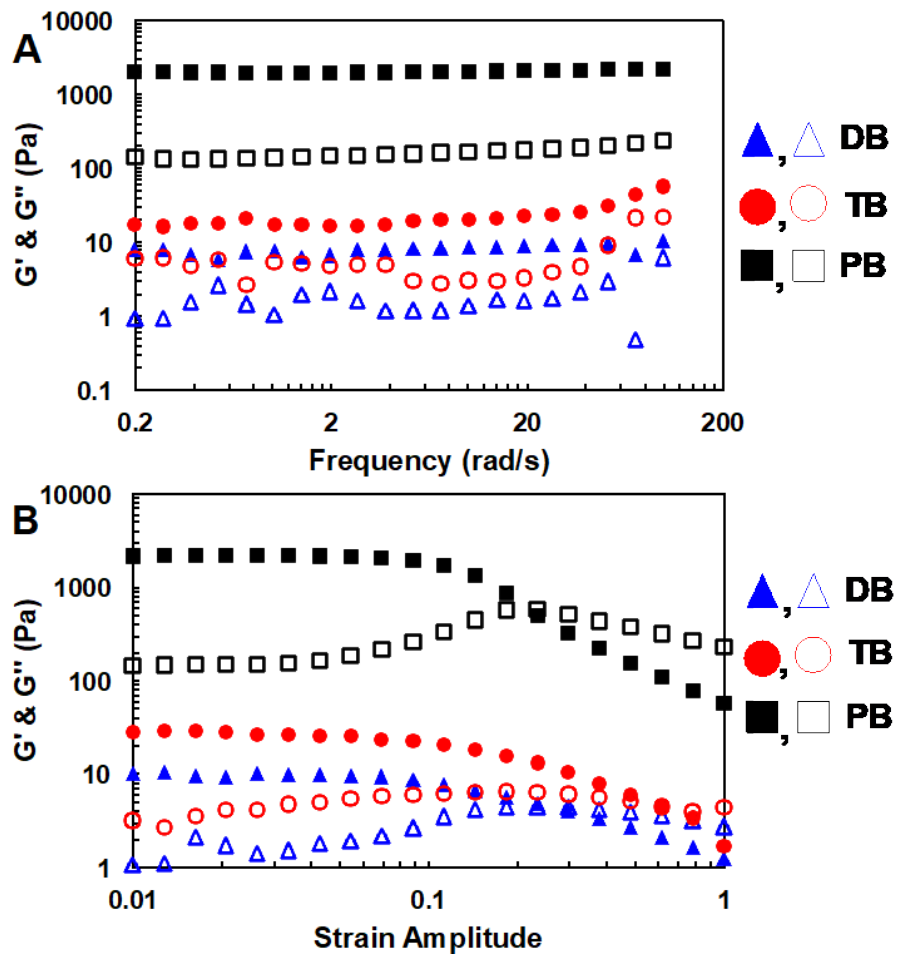

Figure S2. Rheology data for PIC diblock (DB), triblock (TB) and pentablock (PB)

hydrogels at $7 \mathrm{wt} \%$ in $1 x \mathrm{PBS}$ buffer at $20^{\circ} \mathrm{C}$. (A) G' (Pa, solid symbols) and G" (Pa, open symbols) of PIC block copolypeptide hydrogels as functions of angular frequency at constant strain amplitude of 0.01. (B) Storage modulus, G' (Pa, solid symbols), and loss modulus, G" (Pa, open symbols), of PIC block copolypeptide hydrogels as functions of strain amplitude at a constant frequency of $5 \mathrm{rad} / \mathrm{s}$. 
Table S2. Rheology data summary for PIC block copolypeptide hydrogels.

\begin{tabular}{|c|c|c|c|}
\hline Sample & wt\% & G' $^{\prime}(\mathbf{P a})$ & G' $^{\prime}(\mathbf{P a})$ \\
\hline Diblock & 5.0 & 3.93 & 1.19 \\
\hline Diblock & 7.0 & 6.52 & 2.10 \\
\hline Diblock & 10.0 & 47.1 & 5.12 \\
\hline Triblock & 5.0 & 6.78 & 1.03 \\
\hline Triblock & 7.0 & 22.5 & 5.84 \\
\hline Triblock & 10.0 & 237 & 11.7 \\
\hline Pentablock & 5.0 & 335 & 22.8 \\
\hline Pentablock & 7.0 & 1990 & 147 \\
\hline Pentablock & 10.0 & 4200 & 299 \\
\hline
\end{tabular}

Data for $5 \mathrm{rad} / \mathrm{s}$ and strain amplitude $=0.01$.

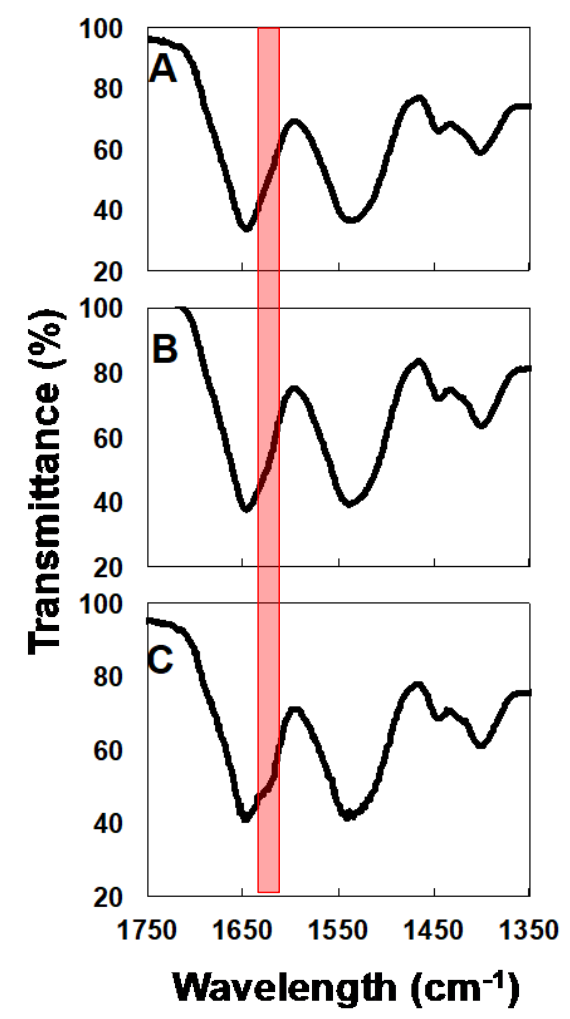

Figure S3. ATR-IR spectra showing the amide region for lyophilized PIC (A) diblock, (B) triblock and (C) pentablock copolypeptide hydrogel samples. Red box highlights area around $1630 \mathrm{~cm}^{-1}$ Amide I band characteristic of $\beta$-sheet chain conformations. Amide I band at 1630 $\mathrm{cm}^{-1}$ is more pronounced in pentablock sample (C), suggesting increased $\beta$-sheet content 
compared to corresponding diblock and triblock samples. Note that the majority of polymer composition in all samples is the $\left(\mathrm{M}^{\mathrm{O}} \mathrm{A}\right)_{\mathrm{n}}$ segments, which are in disordered chain conformations and result in the large $1653 \mathrm{~cm}^{-1}$ Amide I band.

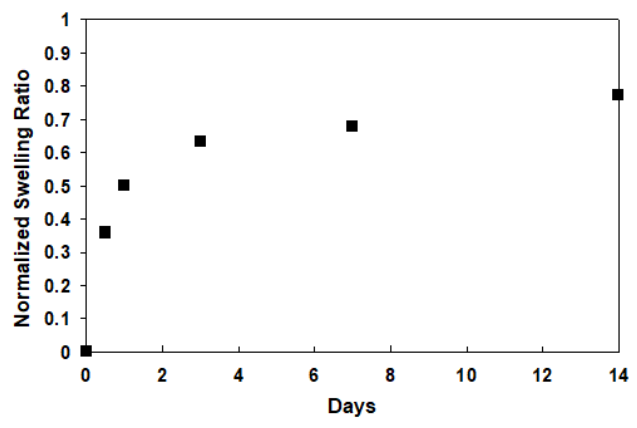

Figure S4. Normalized swelling ratio measurement. A sample of pentablock PIC hydrogel prepared at $10 \mathrm{wt} \%$ in $1 \times \mathrm{PBS}$ was diluted with an equal volume of DMEM cell culture media. Hydrogel swelling was monitored by removal of all supernatant liquid above the hydrogel at different time points. Normalized swelling ratio was calculated as: (weight of sample after swelling - weight of initial hydrogel sample) / weight of initial hydrogel sample.
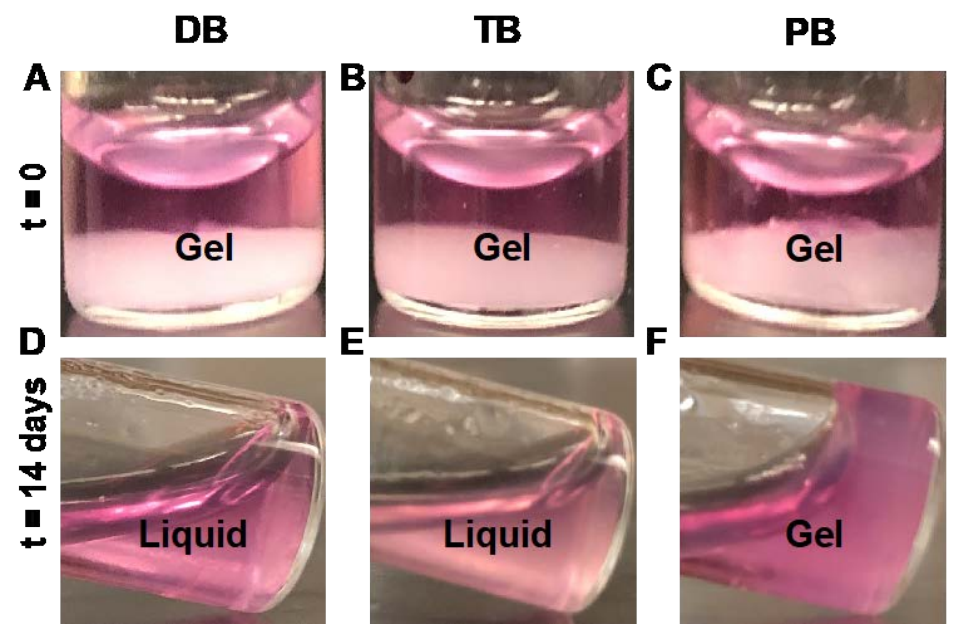

Figure S5. Stability of multiblock PIC copolypeptide hydrogels against dilution. Diblock (DB), triblock (TB), and pentablock (PB) PIC hydrogels prepared at $10 \mathrm{wt} \%$ in $1 \times \mathrm{PBS}$ were 
each diluted with an equal volume of DMEM cell culture media. (A, B, C) A separate layer of cell media formed over all hydrogels at the beginning of the experiment (time $=0) .(D, E$, F) After 14 days, the pentablock hydrogel remained intact, while the diblock and triblock samples had dispersed into the media.

\section{General procedure for copolypeptide synthesis}

All polymerization reactions were performed in an $\mathrm{N}_{2}$ filled glove box using anhydrous solvents. To a solution of L-methionine NCA (Met NCA) and L-alanine NCA (Ala NCA) in THF (50 mg/ml) was added a solution of $\mathrm{Co}\left(\mathrm{PMe}_{3}\right)_{4}$ in THF $(20 \mathrm{mg} / \mathrm{ml}) .{ }^{1}$ The reactions were let to stir at ambient temperature $\left(\mathrm{ca} .22^{\circ} \mathrm{C}\right.$ ) for $60 \mathrm{~min}$. Complete consumption of NCA was confirmed by FTIR spectroscopy, and then the desired amount of $\gamma$-benzyl-L-glutamate NCA (Bn-Glu NCA) or $\varepsilon$-trifluoroacetyl-L-lysine NCA (TFA-Lys NCA) in THF (50 mg/ml) was added to the reaction mixtures, which were let to stir for an additional $60 \mathrm{~min}$. FTIR was used to confirm complete consumption of all NCAs. Monomer additions were repeated as necessary. Once polymerizations were completed the block copolypeptide solutions were removed from the glove box, precipitated into $10 \mathrm{mM} \mathrm{HCl}(20 \mathrm{ml})$, and then washed with 10 $\mathrm{mM}$ aqueous $\mathrm{HCl}(2 \times 20 \mathrm{ml})$ to remove residual cobalt ions. The white precipitates were then washed with DI water $(3 \times 20 \mathrm{ml})$ and freeze-dried to give products as white solids. ${ }^{1}$ Subsequent oxidation of samples, followed by deprotection of Bn-Glu or TFA-Lys groups were performed as previously described. ${ }^{2}$ 
Poly(L-methionine sulfoxide ${ }_{0.88}$-stat-L-alanine $\left.{ }_{0.12}\right)_{100}$-block-poly(L-lysine $)_{30},\left(\mathrm{M}^{\mathrm{O}} \mathrm{A}\right)_{100} \mathrm{~K}_{30}$ and poly(L-methionine sulfoxide0.88-Stat-L-alanine0.12)100-block-poly(L-glutamate)30, $\left(\mathrm{M}^{\mathrm{O}} \mathrm{A}\right){ }_{100 \mathrm{E}} \mathrm{E}$

These samples were prepared as previously described. ${ }^{2}$

Poly(L-methionine sulfoxide 0.88 -stat-L-alanine $\left.{ }_{0.12}\right)_{50}$-block-poly(L-lysine) 30 -block-poly(Lmethionine sulfoxide 0.88 -stat-L-alanine $\left.{ }_{0.12}\right)_{50},\left(\mathrm{M}^{\mathrm{O}} \mathrm{A}\right)_{50} \mathrm{~K}_{30}\left(\mathrm{M}^{\mathrm{O}} \mathrm{A}\right)_{50}$ and poly $(\mathrm{L}$ methionine sulfoxide0.88-stat-L-alanine0.12)50-block-poly(L-glutamate)30-block-poly(Lmethionine sulfoxide 0.88 -stat-L-alanine 0.12$)_{50},\left(\mathrm{M}^{\mathrm{O}} \mathrm{A}\right)_{50} \mathrm{E}_{30}\left(\mathrm{M}^{\mathrm{O}} \mathrm{A}\right)_{50}$ In the glove box, a stock solution of Met NCA (110 mg, $0.62 \mathrm{mmol})$ mixed with Ala NCA (9.9 mg, $0.085 \mathrm{mmol}$ ) was prepared using THF (2.2 ml) and placed in a $20 \mathrm{ml}$ scintillation vial. First block synthesis: The desired amount of Met/Ala NCA stock solution (1.2 ml) was added to a $20 \mathrm{ml}$ scintillation vial containing a stir bar. To the vial, $\left(\mathrm{PMe}_{3}\right)_{4} \mathrm{Co}$ initiator solution (500 $\mu$ l of a $20 \mathrm{mg} / \mathrm{ml}$ solution in THF) was added via syringe. The vial was sealed and allowed to stir in the glove box for $1 \mathrm{~h}$. An aliquot (20 $\mu \mathrm{l})$ was removed and analyzed by FTIR to confirm that all the NCA was consumed. In the glove box, $\alpha$-methoxy- $\omega$ isocyanoethyl-poly(ethylene glycol) ${ }_{45}\left(\mathrm{mPEG}_{23}-\mathrm{NCO}\right)(20 \mathrm{mg})$ was dissolved in THF (1 ml) in a $20 \mathrm{ml}$ scintillation vial. An aliquot $(550 \mu \mathrm{l})$ of the polymerization solution containing active chain ends was removed and added to the solution of $\mathrm{mPEG}_{23}-\mathrm{NCO}$. The PEG endcapped sample (MA50-mPEG 23 ) was sealed, allowed to stir for $24 \mathrm{~h}$, and then used for chain length determination (vide infra). Second block synthesis: Separately, aliquots of the polymerization solution containing active chains ( $0.4 \mathrm{ml}$ each) were added to vials containing either Bn-Glu NCA (21 mg, 0.078 mmol) or TFA-Lys NCA (21 mg, 0.078 mmol) dissolved 
in THF (410 $\mu \mathrm{l}$ or $420 \mu \mathrm{l}$, respectively). The vials were sealed and allowed to stir in the glove box for $1 \mathrm{~h}$ to give the diblock copolypeptides, (MA) $)_{50}(\mathrm{TFA}-\mathrm{K})_{30}$ and (MA) $)_{50}(\mathrm{Bn}-\mathrm{E})_{30}$. FTIR was used to confirm complete consumption of NCAs in both reactions. Aliquots (400 $\mu$ l) of each polymerization solution were removed for ${ }^{1} \mathrm{H}$ NMR analysis to determine the second block lengths. Third block synthesis: $470 \mu \mathrm{l}$ of the Met/Ala NCA stock solution was added

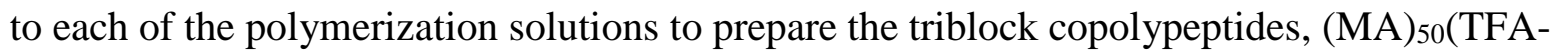
$\mathrm{K})_{30}(\mathrm{MA})_{50}$ and (MA) $)_{50}(\mathrm{Bn}-\mathrm{E})_{30}(\mathrm{MA})_{50}$. The solutions were allowed to stir for $1 \mathrm{hr}$ and were checked by FTIR to ensure completed NCA consumption. Outside the glove box, the triblock copolypeptide solutions were precipitated into $10 \mathrm{mM} \mathrm{HCl}(20 \mathrm{ml})$, and then washed with 10 $\mathrm{mM}$ aqueous $\mathrm{HCl}(2 \times 20 \mathrm{ml})$ to remove residual cobalt ions. The white precipitates were then washed with DI water (3 x $20 \mathrm{ml}$ ) and freeze-dried (94\% average yield). ${ }^{2}$ Subsequent oxidation of samples, followed by deprotection of Bn-Glu or TFA-Lys groups were performed as previously described. ${ }^{2}$

Poly(L-methionine sulfoxide0.88-stat-L-alanine0.12)50-block-poly(L-lysine)30-block-poly(Lmethionine sulfoxide 0.88 -stat-L-alanine 0.12$)_{100}$-block-poly(L-lysine) ${ }_{30}$-block-poly(Lmethionine sulfoxide 0.88 -stat-L-alanine $\left.{ }_{0.12}\right)_{50},\left(M^{\mathrm{O}} \mathrm{A}\right)_{50} \mathrm{~K}_{30}\left(\mathrm{M}^{\mathrm{O}} \mathrm{A}\right)_{100} \mathrm{~K}_{30}\left(\mathrm{M}^{\mathrm{O}} \mathrm{A}\right)_{50}$ and poly(L-methionine sulfoxide 0.88 -stat-L-alanine 0.12$)_{50}$-block-poly(L-glutamate) 30 -blockpoly(L-methionine sulfoxide0.88-stat-L-alanine 0.12 )100-block-poly(L-glutamate) ${ }_{30}$-blockpoly(L-methionine sulfoxide. 0.88 -stat-L-alanine 0.12$)_{50},\left(\mathrm{M}^{\mathrm{O}} \mathrm{A}\right)_{50} \mathrm{E}_{30}\left(\mathrm{M}^{\mathrm{O}} \mathrm{A}\right)_{100} \mathrm{E}_{30}\left(\mathrm{M}^{\mathrm{O}} \mathrm{A}\right)_{50}$ A stock solution of Met NCA (240 mg, $1.4 \mathrm{mmol}$ ) mixed with Ala NCA (22 mg, $0.19 \mathrm{mmol}$ ) was prepared using THF (4.8 ml) and placed in a $20 \mathrm{ml}$ scintillation vial. $50 \mathrm{mg} / \mathrm{ml}$ stock solutions of Bn-Glu NCA (45 mg, $0.17 \mathrm{mmol}$ ) and TFA-Lys NCA (45 mg, $0.17 \mathrm{mmol}$ ) were 
also prepared using THF in $20 \mathrm{ml}$ scintillation vials. First block synthesis: The desired amount of Met/Ala NCA stock solution $(1.2 \mathrm{ml})$ was added to a $20 \mathrm{ml}$ scintillation vial containing a stir bar. To the vial, $\left(\mathrm{PMe}_{3}\right)_{4} \mathrm{Co}$ initiator solution $(500 \mu \mathrm{l}$ of a $20 \mathrm{mg} / \mathrm{ml}$ solution in THF) was added via syringe. The vial was sealed and allowed to stir in the glove box for 1 h. An aliquot (20 $\mu \mathrm{l})$ was removed and analyzed by FTIR to confirm that all the NCA was consumed. In the glove box, $\alpha$-methoxy- $\omega$-isocyanoethyl-poly(ethylene glycol) $)_{45}\left(\mathrm{mPEG}_{23-}\right.$ NCO) (20 mg) was dissolved in THF (1 ml) in a $20 \mathrm{ml}$ scintillation vial. An aliquot (550 $\mu \mathrm{l})$ of the polymerization solution containing active chain ends was removed and added to the solution of $\mathrm{mPEG}_{23}-\mathrm{NCO}$. The PEG end-capped sample $\left(\mathrm{MA}_{50}-\mathrm{mPEG}_{23}\right)$ was sealed, allowed to stir for $24 \mathrm{~h}$, and then used for chain length determination (vide infra). Second block synthesis: Separately, aliquots of the polymerization solution containing active chains (0.4 ml each) were added to vials containing either Bn-Glu NCA (410 $\mu$ l of stock) or TFALys NCA (420 $\mu \mathrm{l}$ of stock). The vials were sealed and allowed to stir in the glove box for $1 \mathrm{~h}$ to give the diblock copolypeptides, (MA) ${ }_{50}(\mathrm{TFA}-\mathrm{K})_{30}$ and (MA) ${ }_{50}(\mathrm{Bn}-\mathrm{E})_{30}$. FTIR was used to confirm complete consumption of NCAs in both reactions. Aliquots (400 $\mu \mathrm{l})$ of each polymerization solution were removed for NMR analysis to determine the second block lengths. Third block synthesis: $470 \mu \mathrm{l}$ of the Met/Ala NCA stock solution was added to each of the polymerization solutions to give the triblock copolypeptides, (MA) ${ }_{50}$ (TFA$\mathrm{K})_{30}(\mathrm{MA})_{50}$ and (MA)50(Bn-E) $)_{30}(\mathrm{MA})_{50}$. The solutions were allowed to stir for $1 \mathrm{hr}$ and were checked by FTIR to ensure completed NCA consumption. Aliquots (400 $\mu \mathrm{l})$ of each polymerization solution were removed for ${ }^{1} \mathrm{H}$ NMR analysis to determine the third block lengths. Fourth block synthesis: $180 \mu \mathrm{l}$ of each Bn-Glu NCA and TFA-Lys NCA stock solution was added to the corresponding polymerization solution to give the tetrablock 
copolypeptides, (MA) $)_{50}(\mathrm{TFA}-\mathrm{K})_{30}(\mathrm{MA})_{50}(\mathrm{TFA}-\mathrm{K})_{30}$ and (MA) $)_{50}(\mathrm{Bn}-\mathrm{E})_{30}(\mathrm{MA})_{50}(\mathrm{Bn}-\mathrm{E})_{30}$. The solutions were allowed to stir for $1 \mathrm{hr}$ and were checked by FTIR to ensure completed NCA consumption. Aliquots $(400 \mu \mathrm{l})$ of each polymerization solution were removed for ${ }^{1} \mathrm{H}$ NMR analysis to determine the fourth block lengths. Fifth block synthesis: $110 \mu \mathrm{l}$ of the Met/Ala NCA stock solution was added to each of the polymerization solutions to give the final pentablock copolypeptides, (MA) $)_{50}(\mathrm{TFA}-\mathrm{K})_{30}(\mathrm{MA})_{50}(\mathrm{TFA}-\mathrm{K})_{30}(\mathrm{MA})_{50}$ and (MA) ${ }_{50}(\mathrm{Bn}-$ E) ${ }_{30}(\mathrm{MA})_{50}(\mathrm{Bn}-\mathrm{E})_{30}(\mathrm{MA})_{50}$. The solutions were allowed to stir for $24 \mathrm{hr}$ and were checked by FTIR to ensure completed NCA consumption. Outside the glove box, the pentablock copolypeptide solutions were precipitated into $10 \mathrm{mM} \mathrm{HCl}(20 \mathrm{ml})$, and then washed with 10 $\mathrm{mM}$ aqueous $\mathrm{HCl}(2 \times 20 \mathrm{ml})$ to remove residual cobalt ions. The white precipitates were then washed with DI water (3 x $20 \mathrm{ml})$ and freeze-dried (97\% average yield). ${ }^{2}$ Subsequent oxidation of samples, followed by deprotection of Bn-Glu or TFA-Lys groups were performed as previously described. ${ }^{2}$

\section{Sample procedure for $M A_{x}$ chain length determination using end-group analysis}

Outside of the glove box, a PEG end-capped sample ( $\left.\mathrm{MA}_{\mathrm{x}}-\mathrm{mPEG}_{23}\right)$ from above was washed with $10 \mathrm{mM}$ aqueous $\mathrm{HCl}(2 \mathrm{x})$. After stirring for $1 \mathrm{~h}, \mathrm{MA}_{\mathrm{x}}-\mathrm{mPEG}_{23}$ was collected by centrifugation and washed with DI water $(3 \times 20 \mathrm{ml})$ to remove all non-conjugated PPEG$_{23}$ NCO. The remaining $\mathrm{MA}_{\mathrm{x}}-\mathrm{mPEG}_{23}$ was then freeze-dried to remove residual $\mathrm{H}_{2} \mathrm{O}$. To determine $\mathrm{MA}_{\mathrm{x}}$ molecular weights $\left(\mathrm{M}_{\mathrm{n}}\right),{ }^{1} \mathrm{H}$ NMR spectra were obtained. Since it has been shown that end-capping is quantitative for $\left(\mathrm{PMe}_{3}\right)_{4} \mathrm{Co}$ initiated NCA polymerizations when excess isocyanate is used, ${ }^{3}$ integrations of methionine $(\delta 2.70)$ and alanine $(\delta 1.52)$ 
resonances versus the polyethylene glycol resonance at $\delta 3.92$ could be used to obtain both $\mathrm{M}$ to $\mathrm{A}$ ratios and $\mathrm{MA}_{\mathrm{x}}$ lengths.

\section{Rheology measurements on block copolypeptide hydrogels}

An Anton Paar Instruments MCR 302 rheometer with a $25 \mathrm{~mm}$ diameter and $1^{\circ}$ cone plate geometry and solvent trap was used for all measurements. Frequency sweeps were measured at constant strain amplitude of 0.01 . Strain sweeps were measured at a constant frequency of $5 \mathrm{rad} / \mathrm{s}$. All measurements were repeated 3 times for each hydrogel sample and the results were averaged. To evaluate shear thinning and recovery behavior of DCH, the strain amplitude was stepped from 0.01 to 10 , maintained at 10 for 2 min and then returned to 0.01 to evaluate the recovery of mechanical properties at a fixed frequency of $5 \mathrm{rad} / \mathrm{s}$.

\section{Hydrogel swelling measurements}

10 wt\% hydrogels of $\left(\mathrm{M}^{\mathrm{O}} \mathrm{A}\right)_{100} \mathrm{E} / \mathrm{K}_{30}, \quad\left(\mathrm{M}^{\mathrm{O}} \mathrm{A}\right)_{50} \mathrm{~K}_{30}\left(\mathrm{M}^{\mathrm{O}} \mathrm{A}\right)_{50}$ and $\left(\mathrm{M}^{\mathrm{O}} \mathrm{A}\right)_{50} \mathrm{~K}_{30}\left(\mathrm{M}^{\mathrm{O}} \mathrm{A}\right)_{100}$ $\mathrm{K}_{30}\left(\mathrm{M}^{\mathrm{O}} \mathrm{A}\right)_{50}$ were prepared in $2 \mathrm{ml}$ scintillation vials and allowed to stand for $1 \mathrm{hr}$. DMEM cell culture media was then placed on top of each hydrogel sample and all were stored in a refrigerator $\left(0^{\circ} \mathrm{C}\right)$ for different periods of time. At each time point, the supernatant liquid was pipetted out of each sample without disturbing the gel at the bottom. The supernatant volumes were subtracted from the original media volume to determine swelling ratios. The hydrogel samples were also subjected to inversion tests to verify hydrogel integrity. Finally, the supernatant liquid was replaced on top of each hydrogel and incubation of samples allowed to continue. 
${ }^{1} \mathrm{H}$ NMR Spectra of polypeptide samples and intermediates

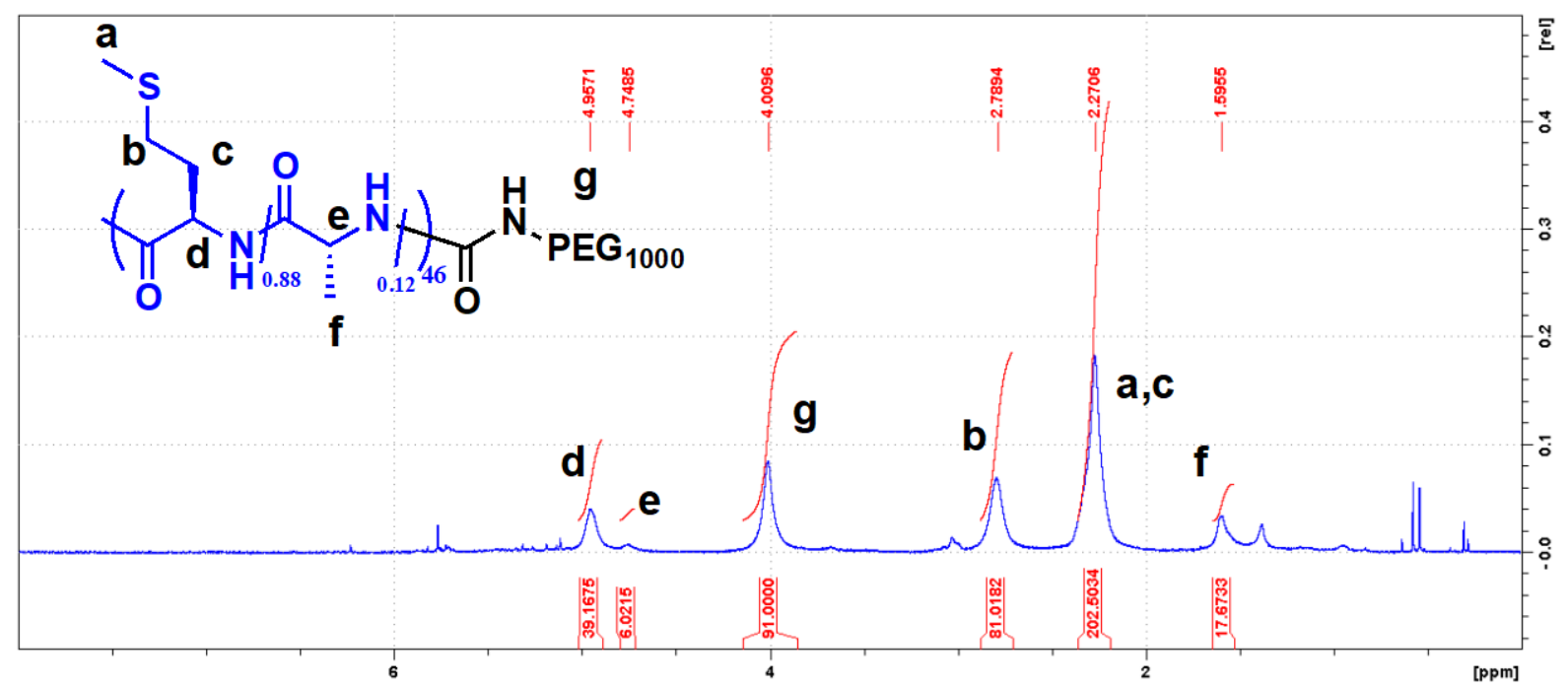

$(\mathrm{MA})_{46}-\mathrm{PEG}_{1000}$ in d-TFA.

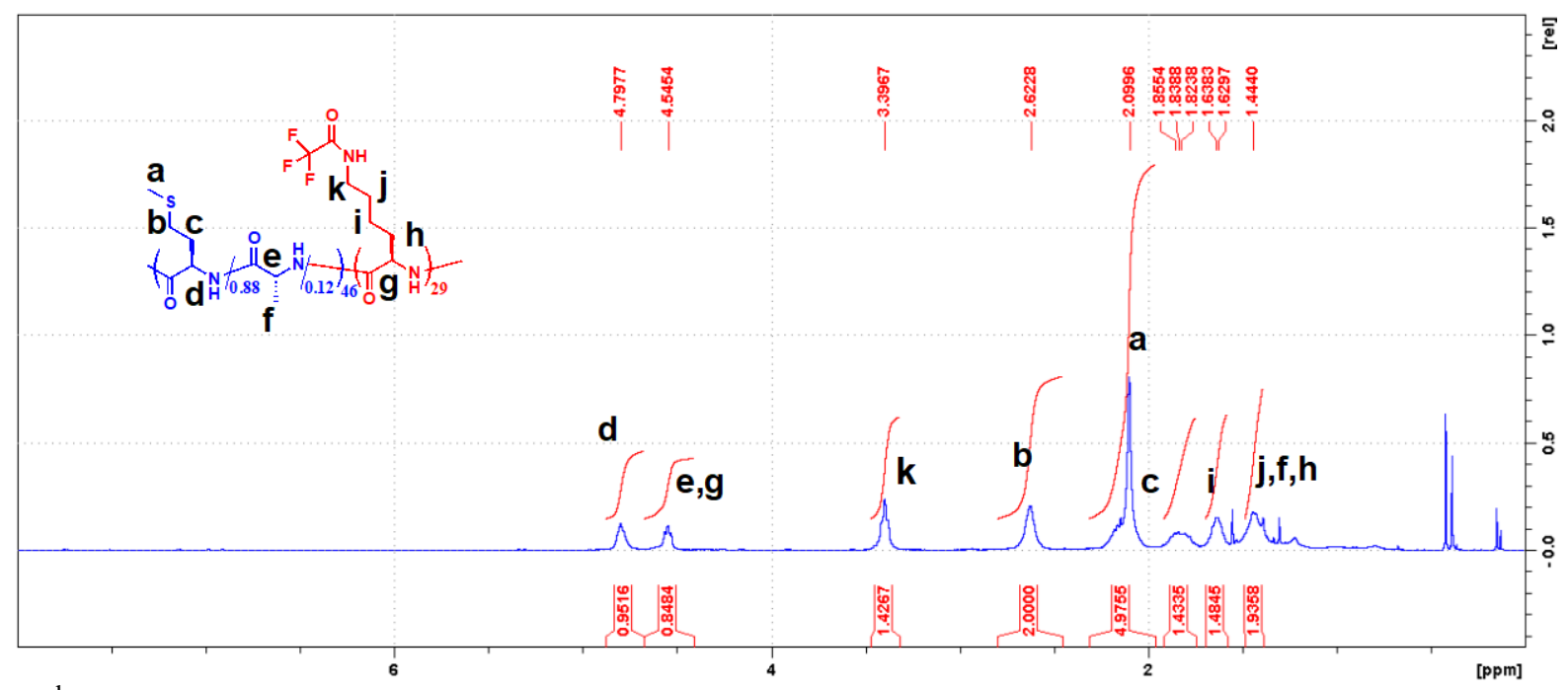

$2^{\text {nd }}$ block addition for triblock, (MA)46(TFA-K) ${ }_{29}$, in d-TFA. 


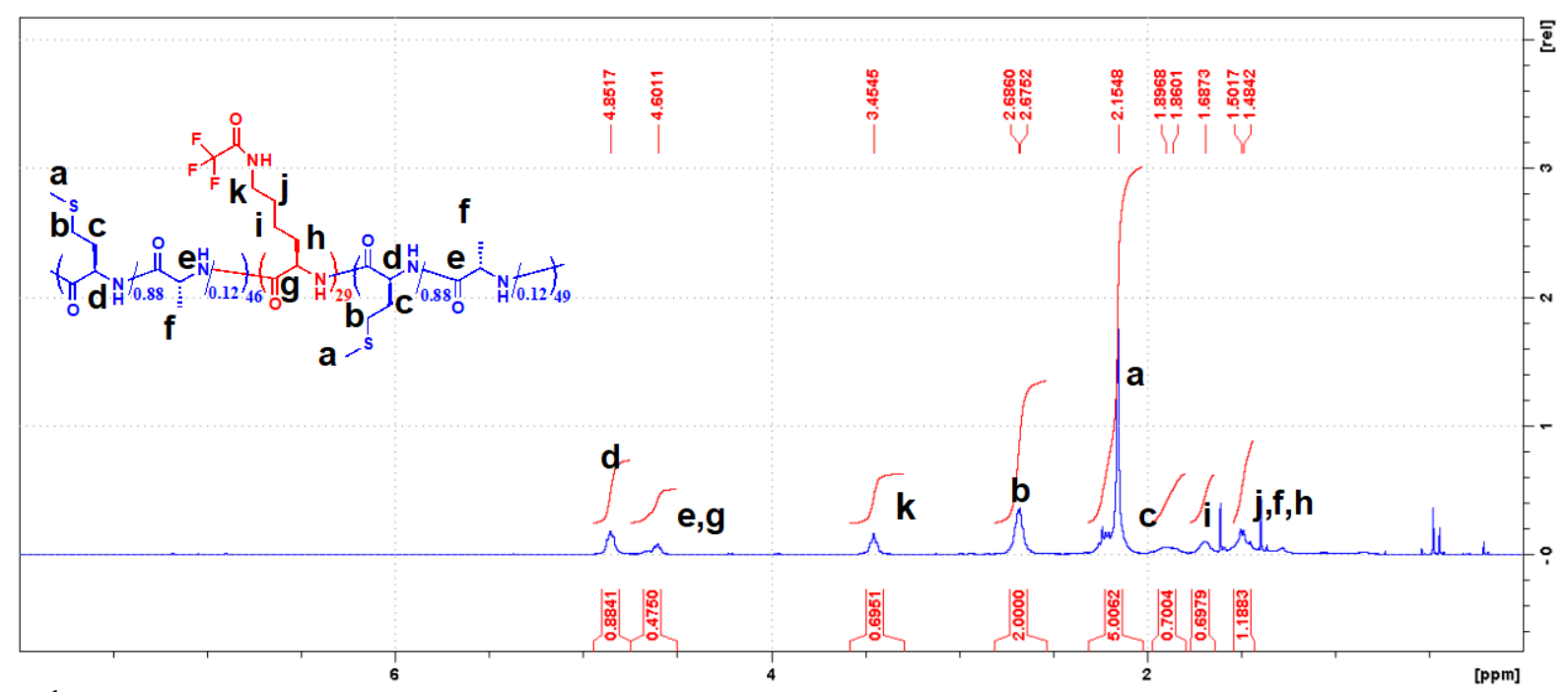

$3^{\text {rd }}$ block addition for triblock, (MA) $)_{46}\left(\right.$ TFA-K) ${ }_{29}(\mathrm{MA})_{49}$, in d-TFA.

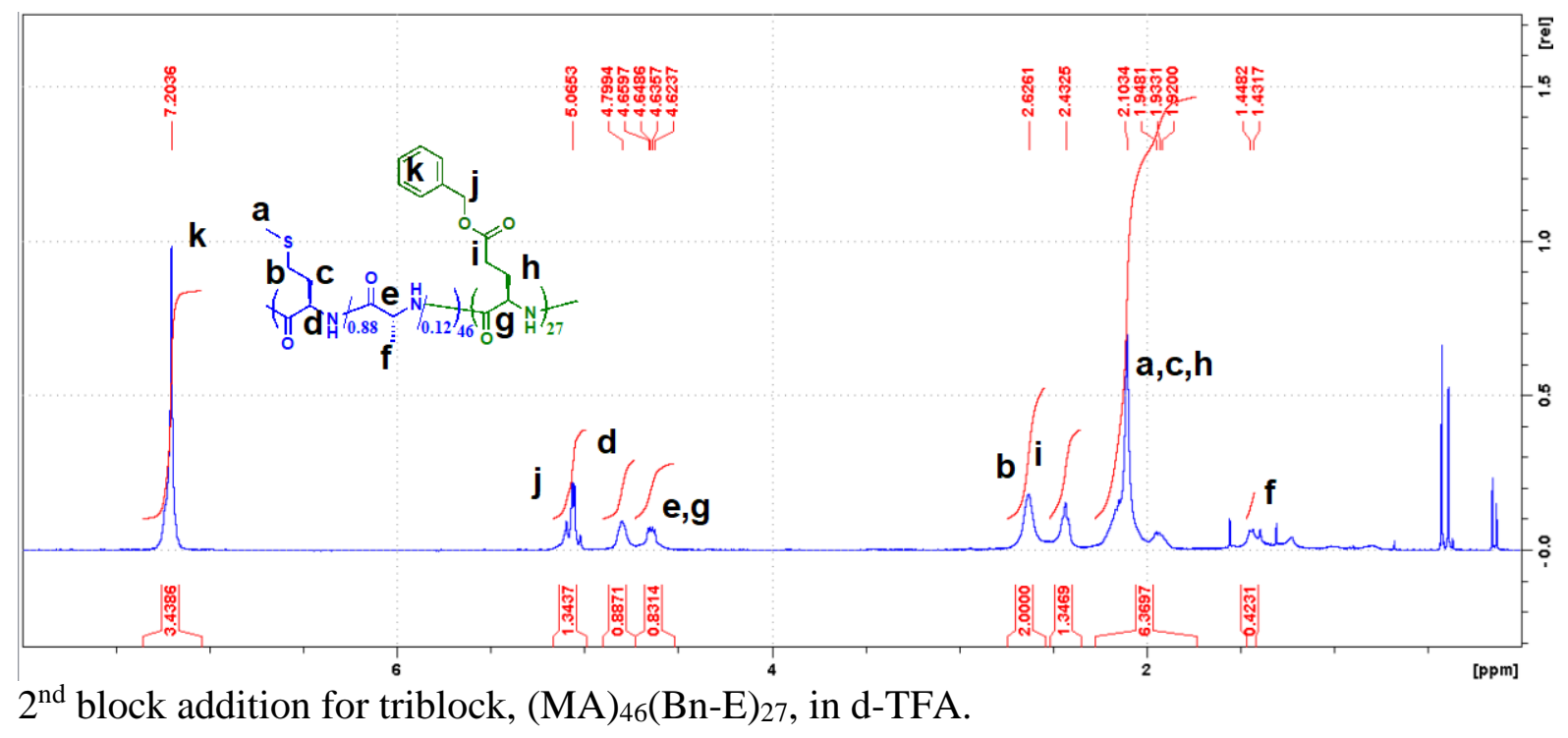




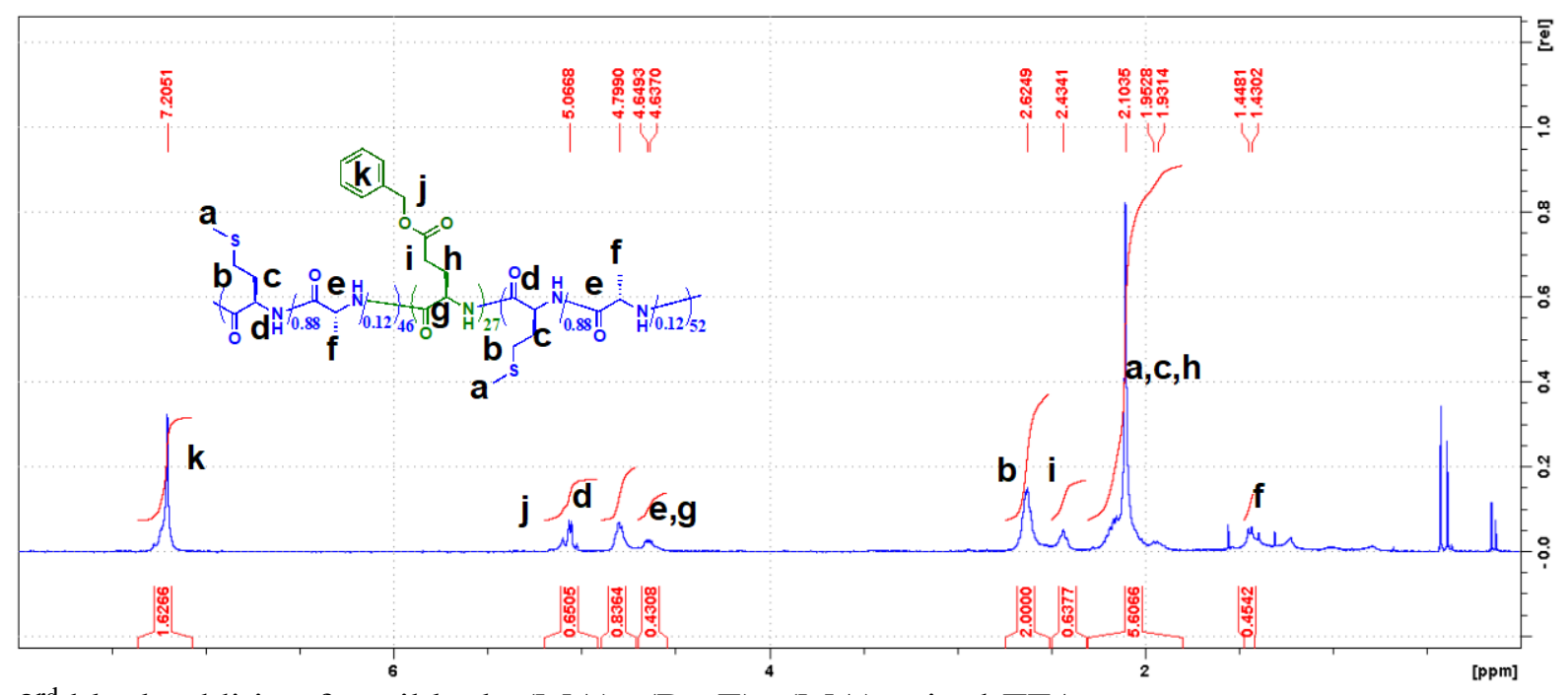

$3^{\text {rd }}$ block addition for triblock, $(\mathrm{MA})_{46}(\mathrm{Bn}-\mathrm{E})_{27}(\mathrm{MA})_{52}$, in d-TFA.

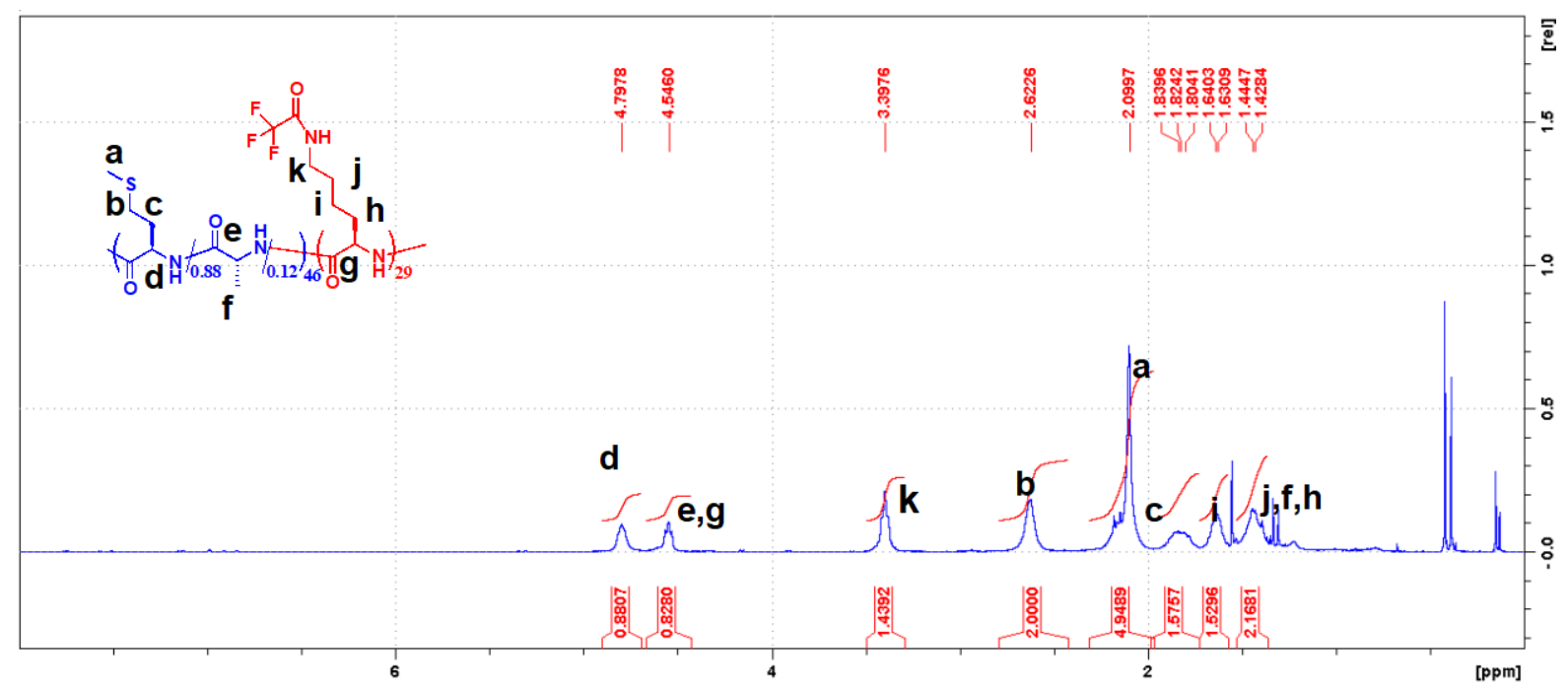

$2^{\text {nd }}$ block addition for pentablock, (MA)46(TFA-K) 29 , in d-TFA. 

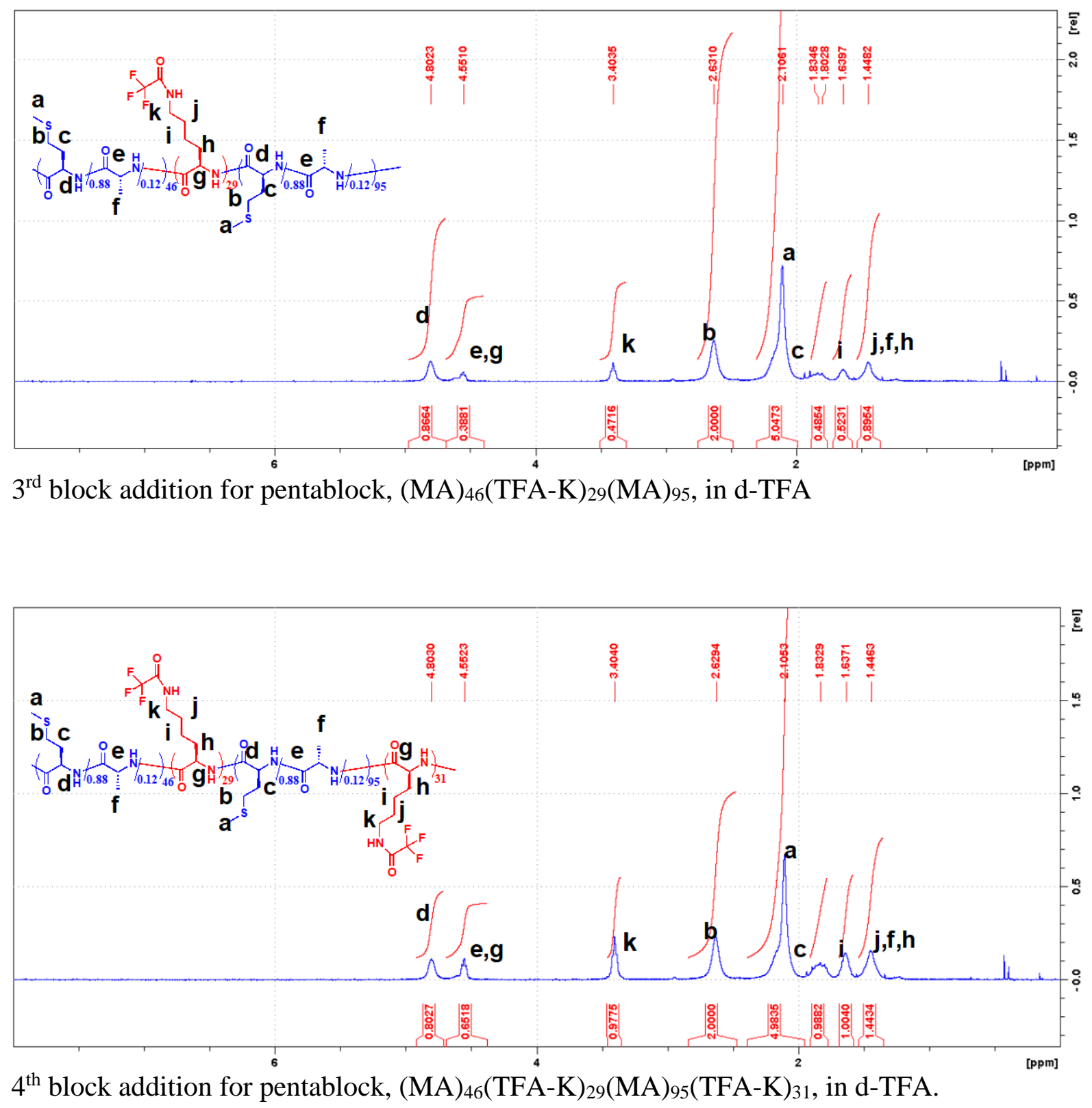


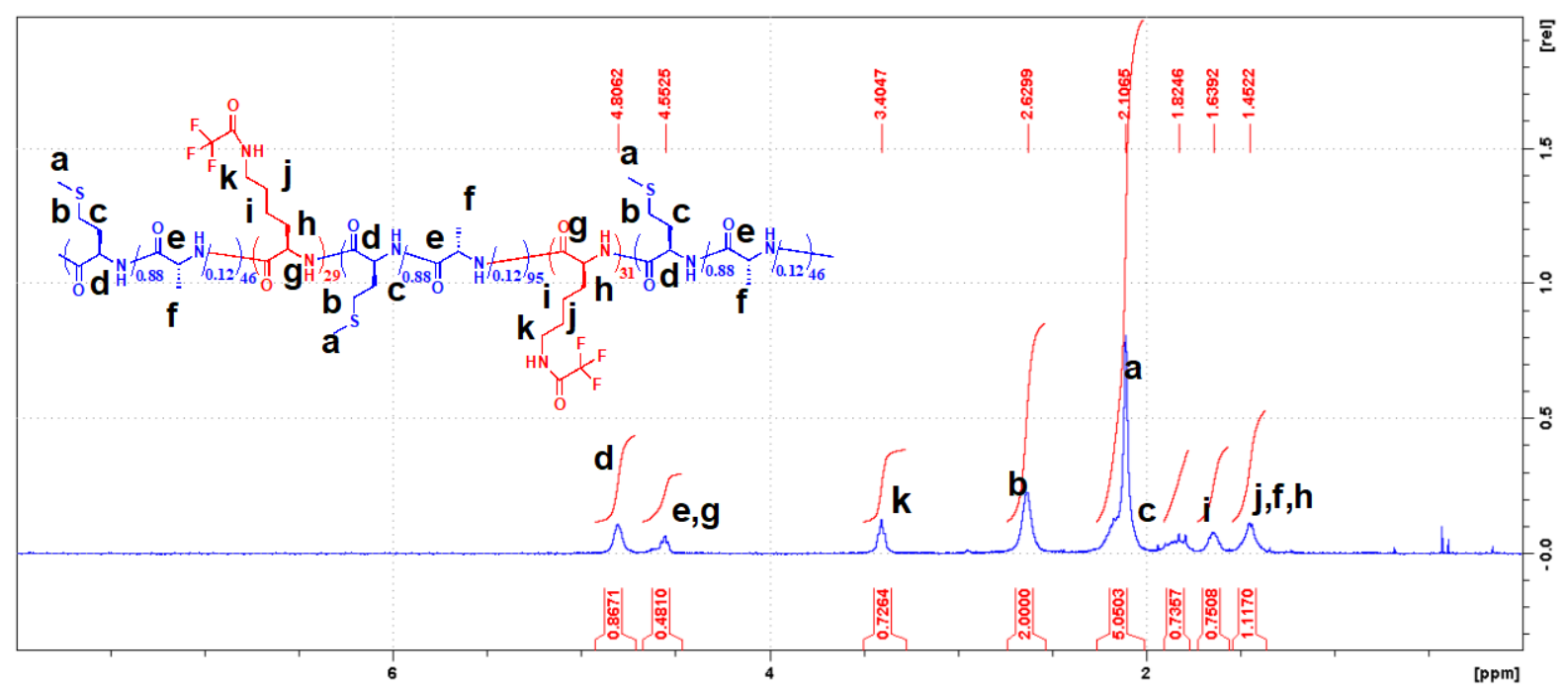

$5^{\text {th }}$ block addition for pentablock, (MA) ${ }_{46}\left(\right.$ TFA-K) ${ }_{29}(\mathrm{MA})_{95}(\mathrm{TFA}-\mathrm{K})_{31}(\mathrm{MA})_{46}$, in d-TFA.

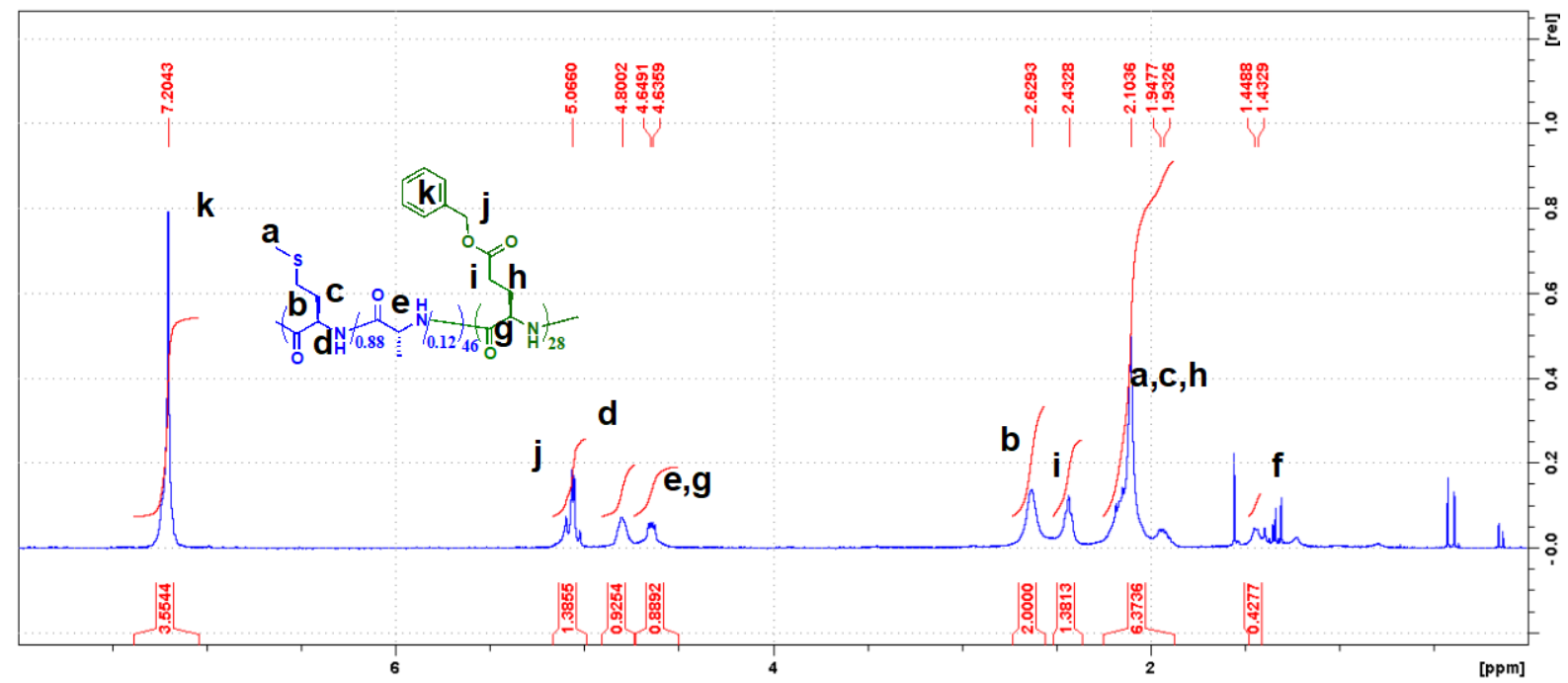

$2^{\text {nd }}$ block addition for pentablock, (MA) ${ }_{46}(\mathrm{Bn}-\mathrm{E})_{28}$, in d-TFA. 


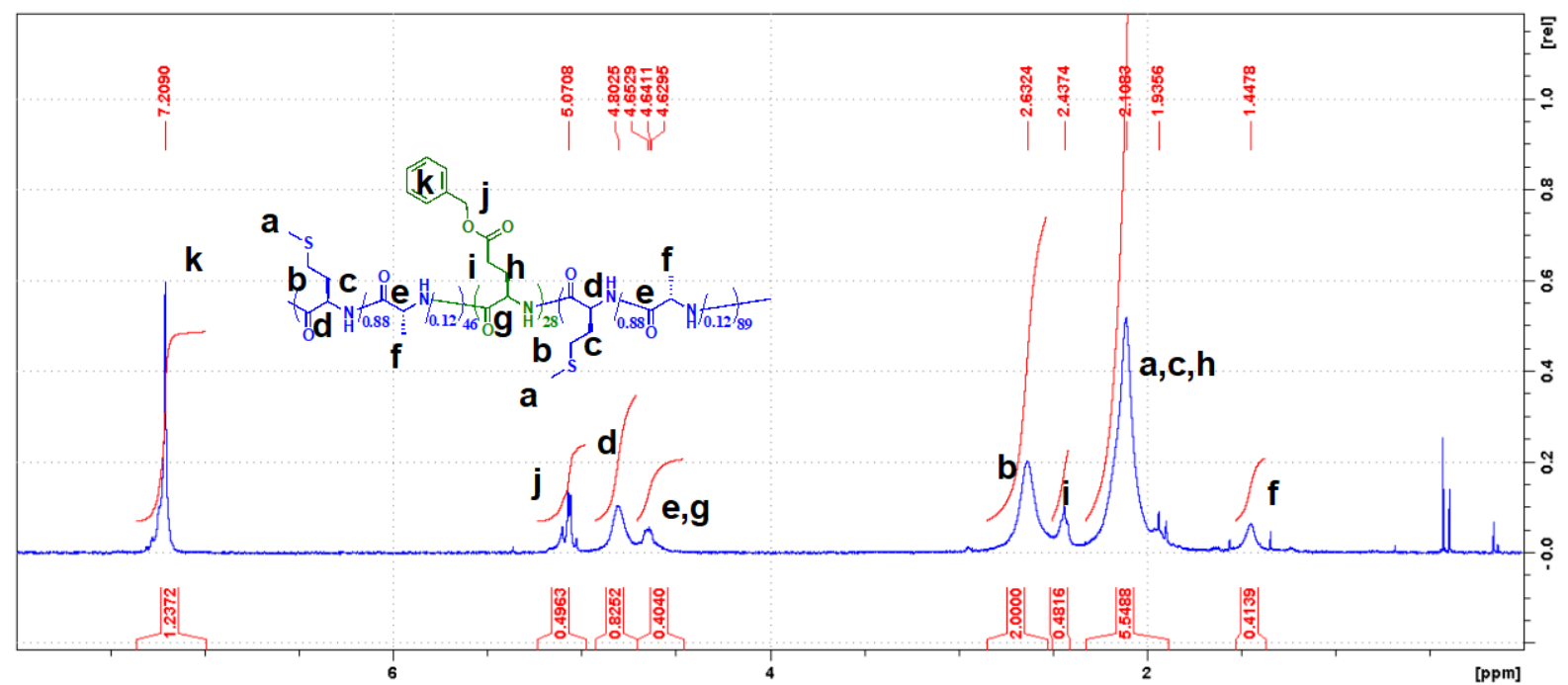

$3^{\text {rd }}$ block addition for pentablock, (MA) $)_{46}(\mathrm{Bn}-\mathrm{E})_{28}(\mathrm{MA})_{89}$, in d-TFA.

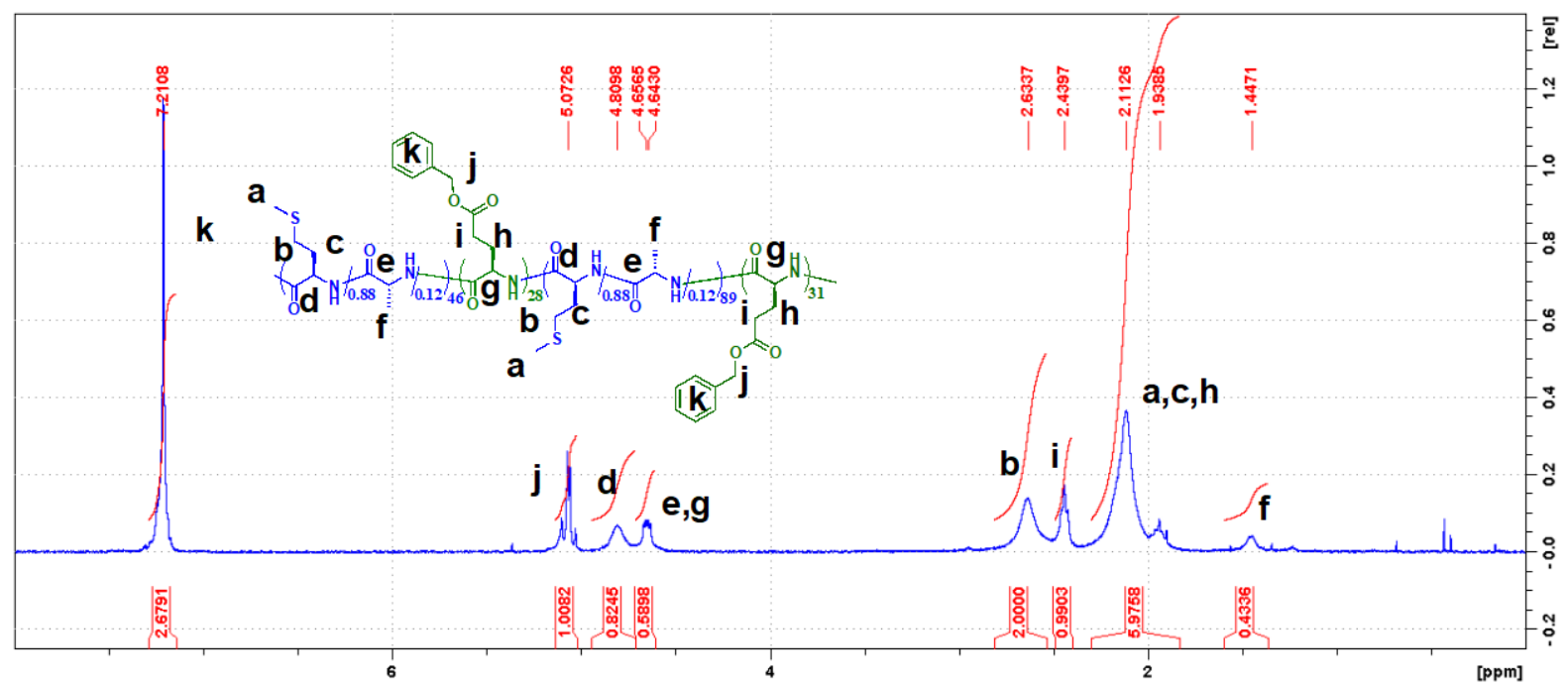

$4^{\text {th }}$ block addition for pentablock, (MA) ${ }_{46}(\mathrm{Bn}-\mathrm{E})_{28}(\mathrm{MA})_{89}(\mathrm{Bn}-\mathrm{E}) 31$, in d-TFA. 


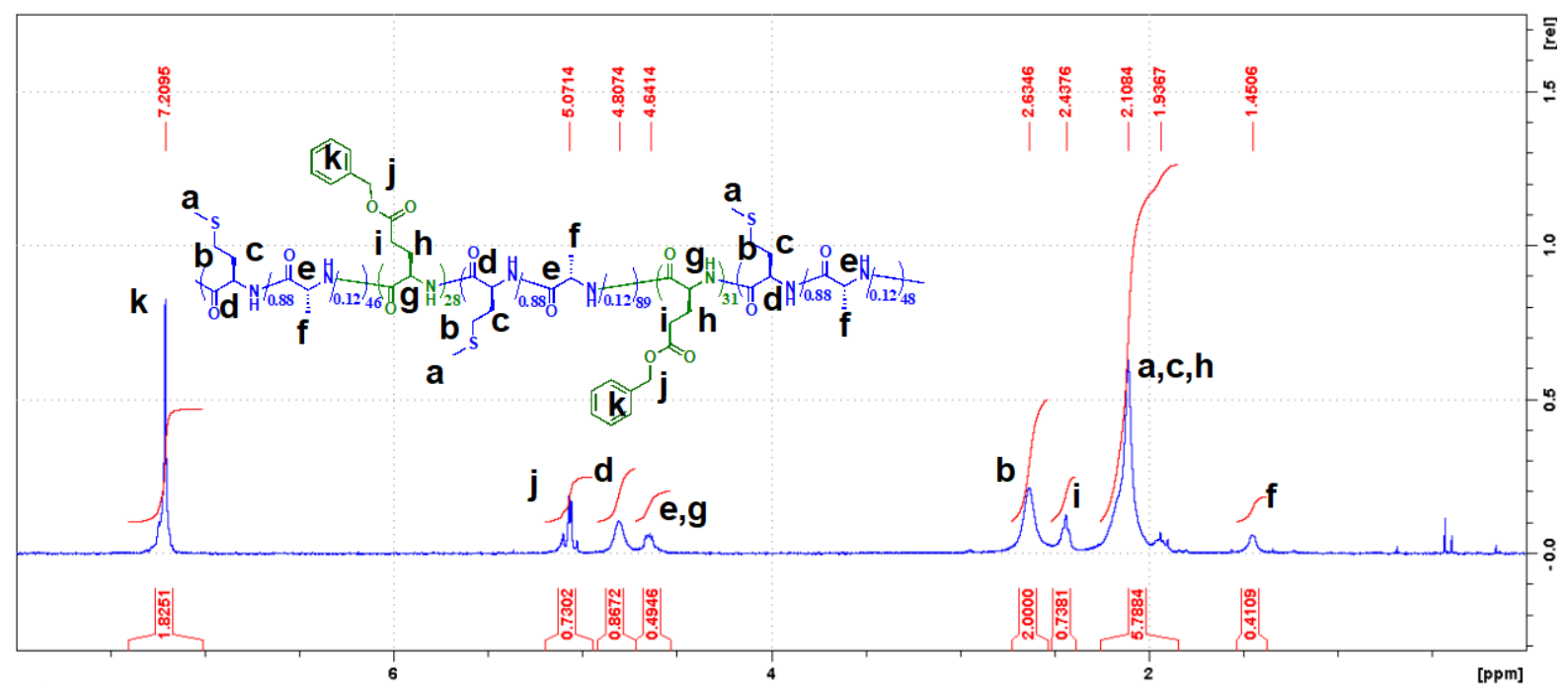

$5^{\text {th }}$ block addition for pentablock, (MA) $)_{46}(\mathrm{Bn}-\mathrm{E})_{28}(\mathrm{MA})_{89}(\mathrm{Bn}-\mathrm{E})_{31}(\mathrm{MA})_{48}$, in d-TFA.

\section{References}

(1) Kramer, J. R.; Deming, T. J. Biomacromolecules 2012, 13, 1719-1723.

(2) Sun, Y.; Wollenberg, A. L.; O’Shea, T. M.; Cui, Y.; Zhou, H.; Sofroniew, M. V.;

Deming, T. J. J. Am. Chem. Soc. 2017, 139, 15114-15121.

(3) Brzezinska, K. R.; Curtin, S. A.; Deming, T. J. Macromolecules 2002, 35, 2970 - 2976. 